\title{
AKUNTABILITAS SOSIAL PADA PEMERINTAHAN LOKAL (Studi Terbentuknya Akuntabilitas Sosial Masyarakat Kelurahan Kalisoro Kecamatan Tawangmangu)
}

\section{SOCIAL ACCOUNTABILITY ON LOCAL GOVERNMENT (Study of Social Accountability Establishment of Urban Village Community Kalisoro sub-district Tawangmangu)}

\author{
Catur Wulandari \\ Pengamat Sosial Bidang Kajian Kemasyarakatan \\ nawang88wulan@yahoo.com
}

\begin{abstract}
ABSTRAK
Reposisi administrasi publik telah menempatkan masyarakat sebagai aktor penting dalam upaya pelayanan public sebagaimana diatur dalam KEPMENPAN 63 / KEP / M.PAN / 7/2003. Akuntabilitas merupakan sarana dan tujuan yang akan dicapai dalam reformasi administrasi. Ketika akuntabilitas tidak berjalan maka masyarakat memiliki kekuasaan untuk memaksakan akuntabilitas. Tujuan dari penelitian ini adalah untuk menentukan akuntabilitas sosial serta faktor-faktor yang mempengaruhinya. Pendekatan dalam penelitian ini memakai pendekatan kualitatif. Analisis data menggunakan pengkodean (coding) terbuka dan tertutup. Data dari setiap wawancara informan berlabel atau kode kemudian muncul kategori. Proses atau elemen yang membentuk akuntabilitas sosial adalah: a) Entry point dalam bentuk kemampuan pemimpin; b) Kemampuan untuk memproses dan menyampaikan tuntutan publik untuk pemimpin; c) Mendukung dari masyarakat; d) Pengiriman Klaim dengan penggunaan media demonstrasi, negosiasi, dan forum evaluasi kerja; e) Respon dari pemerintah; f) Hasil akuntabilitas tidak langsung menjadi media kontrol dalam peningkatan kinerja pemerintah. Faktor-faktor yang mempengaruhi adalah Pertama, kurangnya kemampuan pejabat negara untuk menerapkan tata kelola yang manusiawi (governance manusia). Kedua, karakter masyarakat untuk mengelola potensi yang ada, kemudian mengirimkannya ke pemerintah. Akuntabilitas sosial Kalisoro masyarakat desa terbentuk sebagai hasil dari suara publik terhadap pemerintah atau pemimpin. Penilaian ini kemudian membentuk akuntabilitas sosial dengan tuntutan suksesi kepala.
\end{abstract}

Keywords: Administrative Reform, Social Accountability, Local Government. 


\begin{abstract}
Repositioning the public administration has put the community as an important actor in the public service efforts such as stipulated in KEPMENPAN 63/KEP/M.PAN/7/2003. Accountability is a means and objectives to be achieved in the administrative reform. When accountability is not running then the public has the power to impose accountability called social accountability. The purpose of this study was to determine the social accountability as well as the factors that influence it. Research with qualitative approach and grounded theory study. Research with a qualitative approach because emphasizes the process and meaning. While grounded theory to develop a theory of social accountability and lift the empirical reality into a theory. Analysis of data using the encoding (coding) is open and closed. Data from each informant interviews labeled or coded then appears categories. Categories are then compared to find constancy and see the same pattern of each informant so comes the core categories. Process or elements that make up the social accountability are: a) Entry point in the form of leader's ability; b) The ability to process and deliver public demands to the leader; c) Support from the society; d) Claim delivery with the use of media demonstration, negotiation, and work evaluation forum; e) Response from the government, although it does not establish a specific mechanism; f) The outcome of accountability indirectly becoming a media control in the improvement of government performance. Factors that influence are: First, the lack of ability of state officials to implement humane governance (human governance), due to the limitations form of village government. Second, the character of the citizens or the public, that is the capacity of communities to manage their own and the potential that exists in society and then deliver it to the government. Social Accountability of Kalisoro village communities formed as a result of the public vote against the government or leaders. This assessment then formed social accountability with the demands of headman succession.
\end{abstract}

\title{
Keywords: Administrative Reform, Social Accountability, Local Government
}

\section{PENDAHULUAN}

Pemerintah mengemban peran sentral dalam melaksanakan public interest untuk mewujudkan kesejahteraan masyarakat. Dalam hal ini pemerintah berperan sebagai 'agen' yang melaksanakan public affairs, sedangkan masyarakat merupakan 'principal' yang menyerahkan pelaksanaan urusan publik pada pemerintah. Namun, pemerintahan yang sentralisitis mewujud dalam birokrasi yang sangat sakral. Lengsernya orde baru merupakan puncak dari ketidakefektifan pemerintah dalam mengatasi krisis multidimensi. Hal ini yang memicu munculnya gelombang reformasi, begitu pula reformasi administrasi.

Beralihnya paradigma pemerintahan dari sentralistik ke 
desentralistik membawa harapan peningkatan penyelenggaraan pemerintah. Namun sayangnya reformasi administrasi belum banyak tersentuh. Seiring dengan itu, menurut Sukardi (2007) reposisi administrasi publik memasuki era anti pemerintah, menempatkan masyarakat sebagai aktor publik yang penting. Peran masyarakat ini semakin penting seiring dengan perubahan paradigma dari government ke governance.

Perubahan paradigma tersebut mendorong penguatan kewajiban pemerinta untuk memberi pertanggungjawaban terhadap usaha-usaha yang dilakukan dalam mengelola aset publik. Pertanggungjawaban ini berupa akuntabilitas, ini bermakna bahwa pemerintah yang mampu bertanggungjawab atas tugasnya merupakan pemerintah yang akuntabel. Akuntabilitas menjadi cara dan tujuan yang ingin dicapai dalam reformasi administrasi yang semakin menguatkan peran masyarakat. Rodan dan Hughes (2012), menyatakan bahwa akuntabilitas menjadi elemen penting dalam reformasi pemerintah.

Sudah banyak regulasi yang mengatur tentang akuntabilitas ini diantaranya Keputusan Menteri Pendayagunaan Aparatur Negara
No.63/KEP/M.PAN/7/2003

Tentang Pedoman Umum Penyelenggaraan Pelayanan Publik, menyatakan asas pelayanan publik meliputi transparansi, akuntabilitas, kondisional, partisipatif, kesamaan hak, keseimbangan hak dan kewajiban. Keputusan Menteri Pandayagunaan Aparatur Negara No. 26/KEP/M.PAN/2/2004, juga mengatur tentang petunjuk teknis transparansi dan akuntabilitas penyelenggaraan pelayanan publik. Kemudian pada tahun 2010 Kementerian Negara Pendayagunaan Aparatur Negara dan Reformasi Birokrasi mengeluarkan Peraturan Menteri Negara Pendayagunaan Aparatur Negara dan Reformasi Birokrasi No. 7 Tahun 2010 tentang Pedoman Penilaian Kinerja Unit Pelayanan Publik. Pada tahun 2014 pemerintah juga mengeluarkan Peraturan Pemerintah No. 29 Tahun 2014 Tentang Sistem Akuntabilitas Kinerja Instansi Pemerintah. Berbagai peraturan tersebut merupakan regulasi yang ditujukan untuk meningkatkan akuntabilitas sektor publik. Namun demikian, mekanisme akuntabilitas yang diatur dalam beberapa regulasi tersebut hanya mengatur secara internal untuk menilai pencapaian target organisasi.

Tidak dipenuhinya prinsip pertanggungjawaban pada masyarakat ini mengurangi tingkat 
kepercayaan masyarakat pada pemerintah. Jika masyarakat menilai pemerintah/pemerintah daerah tidak accountable, masyarakat dapat menuntut pergantian pemerintahan, penggantian pejabat, dan sebagainya. Rendahnya akuntabilitas pemerintah inilah yang mendorong masyarakat melakukan movement untuk peningkatan akuntabilitas. Tuntutan yang muncul dari masyarakat ini menciptakan social accountability, yaitu akuntabilitas yang didesakkan oleh masyarakat (Malena et al, 2004). Dalam kajian administrasi publik, Donny Setyawan (2014) dan PATTIRO (2014) menyatakan bahwa akuntabilitas sosial merupakan instrument penilaian dan peningkatan pelayanan publik.

Akuntabilitas sosial ini terjadi pada Kelurahan Kalisoro Kecamatan Tawangmangu. Peran masyarakat sangat besar untuk mengontrol kinerja pemerintah. Kejadian terakhir terjadi pada awal tahun 2014 masyarakat melakukan tuntutan, seperti yang dimuat dalam portal berita berikut:

"Kantor Kelurahan Kalisoro, Kecamatan Tawangmangu, Karanganyar, disegel warga setempat, Sabtu (18/1/2014). Mereka menuntut agar Lurah Kalisoro
Mengundurkan diri dari jabatannya. Aksi para warga dipicu lantaran selama ini pelayanan masyarakat tidak maksimal." (http://jogja.solopos.com)

Berdasarkan regulasi, yang memiliki hak untuk mengangkat dan menghentikan Lurah adalah pemerintah. Kasus yang terjadi pada Kelurahan Kalisoro tersebut menunjukkan bahwa desakan yang dilakukan oleh masyarakat mampu mempengaruhi kebijakan ataupun kualitas pemerintah dengan pergantian Lurah. Kegiatankegiatan yang dilakukan oleh masyarakat tersebut merupakan usaha sebagai tuntutan akuntablilitas karena mekanisme akuntabilitas tidak bekerja dengan baik. Penelitian ini ditujukan untuk mengetahui Akuntabilitas Sosial yang ada pada masyarakat Kelurahan Kalisoro serta faktor yang mempengaruhi Akuntabilitas Sosial pada masyarakat Kelurahan Kalisoro.

\section{KAJIAN PUSTAKA}

\section{Reformasi Administrasi}

$$
\text { Administrasi }
$$

publik memiliki dinamika perkembangan yang adaptif terhadap tuntutan perubahan sosial dan isu-isu baru di masyarakat. Lokus dari ilmu administrasi publik bukan lagi lembaga pemerintah, tetapi masalah dan kepentingan publik 
(publicness) yang bisa diselenggarakan oleh banyak aktor potensial. Perkembangan yang dinamis ini bisa dikelompokkan pada 3 periode:

1) Sebelum tahun 1970-an, dikenal dengan paradigma Old Public Administration (OPA)

2) Tahun 1970 sampai dengan 2003 dikenal dengan paradigma New Public Management (NPM)

3) Tahun 2003 sampai sekarang dikenal dengan New Public Service (NPS)

Seiring dengan perkembangan paradigma tersebut muncul studi governance. Menurut UNDP (1997 dalam Rohman, 2012) governance dimaknai sebagai ".....how government functions and works together with others to make decisions and take actions to deal with the needs of it's citizen" (bagaimana pemerintah berfungsi dan bekerjasama untuk membuat keputusan dan mengambil tindakan yang berkaitan dengan pemenuhan kebutuhan masyarakat). Konsep ini mengalami perluasan dengan munculnya human governance, sound governance dan lainnya. Menurut Utomo (2006), semua konsep baru tersebut menekankan pentingnya birokrasi membalik orientasinya dari sekedar meletakkan manusia sebagai komponen production centered development ke arah people centered development. Ini berarti bahwa segala input sumber daya manusia diperlukan untuk membangun masyarakat secara berswasembada dan swadaya. Wawasan birokrasi haruslah wawasan efisiensi yang mengacu pada pembangunan yang berpusat pada manusia dalam segala aspek keterlibatannya. Reposisi tersebut telah menempatkan masyarakat sebagai third sector yang memiliki peran penting dalam penyelenggaraan negara dan pembangunan masyarakat.

Perkembangan administrasi publik tersebut juga melahirkan reformasi administrasi. Reformasi administrasi publik ini ditujukan untuk meningkatkan kinerja administrasi publik, dimana masyarakat menjadi bagian penting yang tidak boleh diabaikan. Farazmand (2002) menyatakan bahwa, in developing nations, administrative reform often referred to as modernization and change in society to effect social and economic transformation. Di negara berkembang, reformasi administrasi ini identik dengan modernisasi dan perubahan masyarakat untuk mempengaruhi transformasi sosial dan ekonomi. Reformasi administrasi ini 
memiliki kaitan yang erat dengan akuntabilitas. Reformasi administrasi didesakkan oleh akuntabilitas (Kettl, 2000 Dalam Saptawan), ditujukan untuk meningkatkan akuntabilitas (Ackerman, 2004), memiliki elemen akuntabilitas (Rodan dan Hughes, 2012), mengandung prinsip akuntabilitas dan transparansi (King et al, 2013). Sedangkan Boven (2006) melihat akuntabilitas sebagai instrument dan tujuan dalam paradigma new public management. Dengan demikian salah satu pendukung keberhasilan reformasi administrasi adalah bekerjanya akuntabilitas.

Reformasi administrasi di Indonesia didorong keinginan untuk membangun bangsa dan negara dimulai dari penyelenggaraan pemerintahan yang stabil, kuat dan sentralis. Pemerintahan dijalankan dengan pendekatan kekuasaan, keamanan dan pemusatan. Namun implementasinya reformasi tersebut berjalan sangat lambat, jikalau terjadi perubahan hanya pada taraf permukaannya. Sedangkan pada masa pasca reformasi, menurut Thoha (2011), dengan adanya silih bergantinya pemerintah kurang memperhatikan sistem dan tata laksana administrasi negara. Saptawan (2010), menyampaikan bahwa kesibukan Indonesia dengan penataan reformasi politik menyebabkan perhatian terhadap praktik administrasi negara agak tersendat. Akibatnya reformasi dalam sektor administrasi negara menjadi terlambat.

Sebagai upaya reformasi administrasi, pemerintah Indonesia memiliki regulasi mengenai akuntabilitas, diantaranya: Keputusan Menteri Pendayagunaan Aparatur Negara No.63/KEP/M.PAN/7/2003;

Keputusan Menteri Pandayagunaan Aparatur Negara No. 26/KEP/M.PAN/2/2004.

Regulasi dan mekanisme yang ada tersebut secara umum hanya ditujukan pada internal pemerintah saja. Hal ini menunjukkan bahwa masyarakat belum menjadi aktor penting dalam bangunan akuntabilitas pemerintah. Sementara masyarakat pada dasarnya memiliki peran yang penting dalam perbaikan kinerja pemerintah (Ackerman, 2004). Beberapa regulasi mengenai keterlibatan masyarakat dalam penyelenggaraan negara maupun pelayanan publik sudah ada diantaranya PP No 68 Tahun 1999 mengatur peran serta masyarakat dalam penyelenggaraan negara yang bebas dari KKN, UU No 10 Tahun 2004 Mengatur tentang partisipasi masyarakat dalam 
pembentukan perundangundangan, UU No 14 Tahun 2008 menyebutkan peran serta masyarakat dalam infromasi publik, UU No 25 Tahun 2009 menyebutkan bahwa penyelenggaraan pelayanan publik berdasarkan akuntabilitas serta hak dan kewajiban masyarakat dalam pelayanan publik. Masyarakat berhak mengawasi dan memberikan tanggapan, namun belum menempatkan keterlibatan masyarakat dalam penentuan standar dan aturan pelayanan publik.

\section{Akuntabilitas Sosial}

Akuntabilitas merupakan konsep yang muncul dalam paradigma governance. Konsep tersebut menekankan pentingnya peran masyarakat dalam mencapai tata kelola pemerintahan yang baik. Akuntabilitas menurut Malena et al, (2004) merupakan, the obligation of power-holders to account for or take responsibility for their actions. "Power-holders" refers to those who hold political, financial or other forms of power and include officials in government, private corporations, international financial institutions and civil society organizations. Menurut Kumorotomo (2005), akuntabilitas merupakan ukuran yang menunjukkan apakah aktivitas birokrasi publik atau pelayanan yang dilakukan oleh pemerintah sudah sesuai dengan norma dan nilai-nilai yang dianut oleh rakyat dan apakah pelayanan publik tersebut mampu mengakomodasi kebutuhan rakyat yang sesungguhnya.

Malena et al (2004), menyatakan social accountability can be defined as an approach towards building accountability that relies on civic engagement, i.e., in which it is ordinary citizens and/or civil society organizations who participate directly or indirectly in exacting accountability. World Bank (2006), mendefinisikan social accountability, the broad range of actions and mechanism (beyond voting) that citizen can use to hold the state into account, as well as actions on the part of government, civil society, media, and other social actors that promote or facilitate these efforts. Akuntabilitas sosial merupakan bangunan akuntabilitas yang menekankan keterlibatan dari masyarakat.

Secara tradisional, bentuk akuntabilitas sosial ini muncul dalam tindakan masyarakat seperti demonstrasi, protes, kampanye, advokasi, investigasi jurnalisme dan tuntutan hukum untuk kepentingan umum. Bentuk-bentuk akuntabilitas ini mulai mengalami 
perluasan melalui peningkatan ruang dan kesempatan bagi warga negara/keterlibatan masyarakat sipil dengan negara, sehingga membuka interaksi langsung dengan pemerintah. Misalnya, kebijakan publik yang partisipatif, penganggaran partisipatif, pelacakan pengeluaran publik, monitoring warga dan evaluasi pelayanan publik.

Tujuan akuntabilitas sosial (Malena et al, 2004) adalah untuk memperbaiki governance, meningkatkan efektivitas pembangunan dan pemberdayaan. Elemen pembentuk akuntabilitas sosial adalah:

1) Identifikasi titik masuk/ masalah (Malena et al, 2004)

2) Mengelola informasi (Malena et al, 2004), menyampaikan pada pejabat publik dan ranah publik untuk membangun kesepakatan bersama (Malena et al, 2004, UNDP, 2013)

3) Menyiapkan masyarakat (UNDP, 2013) dan membangun koalisi (Malena et al, 2004).

4) Interaksi dan negosiasi (Malena et al, 2004; SAP4Africa, 2013)

5) Respon pemerintah (SAP4Africa, 2013) dan
Mekanisme yang dibangun bersama (UNDP, 2013)

6) Pemantauan Sosial (SAP4Africa, 2013)

Sedangkan faktor yang mempengaruhi akuntabilitas sosial adalah:

1) Karakter

Negara/Pemerintah (UNDP, 2013; Malena et al, 2004)

2) Karakter Warga Negara/masyarakat (UNDP, 2013; Malena et al , 2004, World Bank; 2013)

\section{Pengangkatan Lurah}

$$
\text { Regulasi mengenai }
$$
Kelurahan diatur dalam PP No. 73 Tahun 2005 Tentang Kelurahan. Berdasarakan PP tersebut Kelurahan dipimpin oleh Lurah yang memperoleh limpahan tugas dari Bupati atau Walikota serta bertanggungjawab kepada Bupati/Walikota. Lurah diangkat oleh Bupati/Walikota atas usul Camat dari pegawai negeri sipil yang menguasai pengetahuan teknis pemerintahan dan memenuhi persyaratan sesuai dengan peraturan perundang-undangan. 


\section{METODE PENELITIAN}

Penelitian dilakukan di Kelurahan Kalisoro Kecamatan Tawangmangu. Pemilihan lokasi karena secara empiris peristiwa tersebut terjadi di Kelurahan tersebut. Penelitian menggunakan pendekatan kualitatif karena penelitian ini lebih menekankan pada masalah proses dan makna, untuk menjawab permasalahan penelitian, melalui gejala sosial yang terjadi pada masyarakat.

Sedangkan jenis penelitian yang digunakan adalah penelitian grounded, yaitu one of qualitative research approaches suited to the purpose of theory development (Strauss dan Corbin 1990, 1994, Glaser 1995, 1999, Charman 2000, Parse 2001 dalam Chiovitti 2003). Teori grounded merupakan pendekatan penelitian yang ditujukan untuk pengembangan teori.

Penentuan informan melalui purposive sampling, sehingga diperoleh 10 informan dari berbagai kalangan. Teknik pengumpulan data dengan wawancara mendalam terhadap 10 informan, observasi partisipatif dan nonpartisipatif serta studi dokumen berupa dokumen monografi, media massa dan data web.

\begin{abstract}
Analisis data dilakukan dengan pengodean (koding), pengodean atau koding ini merupakan pelabelan atau pemberian nama terhadap data yang diperoleh dari informan. Tahap pengodean yang dilakukan adalah pengodean terbuka dan pengodean terpilih. Punch (1999) Open coding is about using the data to generate conceptual labels and categories for use in theory building. Sedangkan, selective coding is aimed at developing the abstract, condensed, integrated, and grounded picture of the data referred to in the quote. Pengodean terbuka dilakukan pada elemenelemen pembentuk dan faktor yang mempengaruhi akuntabilitas sosial, dilakukan seperti berikut :
\end{abstract}

Elemen A

\begin{tabular}{|l|l|l|l|}
\hline Sumber & $\begin{array}{l}\text { Kategori } \\
\mathrm{a}\end{array}$ & $\begin{array}{l}\text { Kategori } \\
\mathrm{b}\end{array}$ & $\begin{array}{l}\text { Kategori } \\
\mathrm{cdst}\end{array}$ \\
\hline Informan 1 & & & \\
\hline Informan 2 & & & \\
\hline $\begin{array}{l}\text { Informan } \\
\text { 3 dst }\end{array}$ & & & \\
\hline
\end{tabular}

Setelah pengodean terbuka, proses selanjutnya adalah melakukan pengodean terpilih. Pengodean terpilih dilakukan dengan membandingkan kategori, mencari atau menemukan keajegan informasi serta melihat pola yang sama dari masing-masing informan sehingga muncullah kategori inti. Sehingga pengodean tepilih ini melihat pola yang muncul dari 
pengodean terbuka tersebut, seperti berikut:

\begin{tabular}{|l|c|c|c|}
\hline Pola & $\begin{array}{c}\text { Kategori } \\
\mathrm{a}\end{array}$ & $\begin{array}{c}\text { Kategori } \\
\mathrm{b}\end{array}$ & $\begin{array}{c}\text { Kategori } \\
\mathrm{c} \mathrm{dst}\end{array}$ \\
\hline Pola 1 & & & \\
\hline Pola 2 & & & \\
\hline Pola 3 dst & & & \\
\hline
\end{tabular}

Masing-masing pola kemudian dijelaskan dan disarikan menjadi kategori inti. Pengkodean terpilih ini memberikan gambaran yang lebih abstrak dari sebelumnya. Sementara itu proses analisis ini dilakukan secara terus menerus mulai dari awal pengambilan data sampai dengan kecukupan data terpenuhi. Karenanya dalam penelitian ini dimungkinkan untuk mengambil data secara berulang pada informan ketika dibutuhkan.

\section{HASIL DAN PEMBAHASAN}

Akuntabilitas dimaknai Malena et al (2004) sebagai kewajiban dari pemegang kekuasaan untuk menjelaskan atau bertanggungjawab atas tindakan mereka. Kumorotomo (2005) menyatakan bahwa akuntabilitas menjawab pertanyaan apakah aktivitas birokrasi publik sesuai dengan norma dan nilai yang dianut oleh masyarakat serta apakah pelayanan publik tersebut mengakomodasi kebutuhan rakyat sesungguhnya. Penilaian atau sanksi ini menurut Ackerman (2005) dan Boven (2006) menjadi bagian penting dalam bangunan akuntabilitas. Penilaian ini menunjukkan apakah pemerintah telah bekerja sesuai dengan preferensi publik.

Upaya yang dilakukan masyarakat untuk menuntut pertanggungjawaban pemegang kekuasaan adalah dengan melakukan tuntutan pergantian Lurah. Tuntutan oleh masyarakat ini terjadi sebagai hasil penilaian terhadap aktivitas dan birokrasi publik yang dianggap tidak sesuai dengan masyarakat. Akuntabilitas sosial ini terjadi 3 kali dari tahun 2001 sampai dengan 2014. Bentuk inisiatif, alasan dan tujuan akuntabilitas sosial adalah sebagai berikut :

\begin{tabular}{|c|l|l|l|}
\hline $\begin{array}{c}\text { Akunt } \\
\text { abilitas } \\
\text { Sosial }\end{array}$ & $\begin{array}{c}\text { Kejadian } \\
\mathbf{1}\end{array}$ & $\begin{array}{c}\text { Kejadian } \\
\mathbf{2}\end{array}$ & $\begin{array}{c}\text { Kejadian } \\
\mathbf{3}\end{array}$ \\
\hline $\begin{array}{l}\text { Bentuk } \\
\text { inisiatif }\end{array}$ & $\begin{array}{l}\text { Aksi/ } \\
\text { demonstra } \\
\text { si } \\
\text { Pemuda } \\
\text { dan } \\
\text { masyaraka } \\
\mathrm{t}\end{array}$ & $\begin{array}{l}\text { Negosiasi } \\
\text { Perwakila } \\
\text { n lembaga }\end{array}$ & $\begin{array}{l}\text { Forum } \\
\text { Evaluasi } \\
\text { RT, RW, } \\
\text { Pemuda } \\
\text { dan } \\
\text { masyarak } \\
\text { at }\end{array}$ \\
\hline Alasan & $\begin{array}{l}\text { Track } \\
\text { record }\end{array}$ & $\begin{array}{l}\text { Pelayanan } \\
\text { sosial }\end{array}$ & $\begin{array}{l}\text { Pelayana } \\
\text { nosial } \\
\text { dan } \\
\text { pelayanan } \\
\text { administr } \\
\text { atif }\end{array}$ \\
\hline Tujuan & $\begin{array}{l}\text { Pencabuta } \\
\text { n } \\
\text { pengangka } \\
\text { tan Lurah }\end{array}$ & $\begin{array}{l}\text { Perbaikan } \\
\text { Kinerja }\end{array}$ & $\begin{array}{l}\text { Pergantia } \\
\text { n Lurah }\end{array}$ \\
\hline
\end{tabular}


Tabel 1. Bentuk Inisiatif, Alasan Dan Tujuan Akuntabilitas Sosial

Secara umum akuntabilitas sosial tersebut muncul sebagai hasil penilaian masyarakat terhadap pemerintah atau pemimpin yang dianggap tidak akuntabel karena tidak adanya kesesuaian dengan harapan masyarakat. Penilaian ini kemudian membentuk akuntabilitas sosial dengan tututan pergantian Lurah. Akuntabilitas sosial tersebut muncul sebagai wujud tuntutan masyarakat akan akuntabilitas yang menjadi tugas dari pemimpin. Senada dengan Ackerman (2004) yang menyatakan bahwa masyarakat merupakan kekuatan besar untuk mengokohkan akuntabilitas pemerintah.

Elemen-elemen pembentuk akuntabilitas sosial tersebut antara lain:

1. Identifikasi

Titik Masuk/Masalah

Titik masuk ini muncul berupa masalah dalam masyarakat yang menjadi dasar akuntabilitas sosial. Titik masuk ini berupa:
a. Kepemimpinan
b. Pelayanan sosial
c. Pelayanan administratif
d. Transparansi dan keterbukaan

Beberapa $r$ kategori
tersebut mengerucut pada
kategori inti yaitu: kemampuan
pemimpin untuk menempatkan
masyarakat sebagai warga
negara atau citizen's. Dalam
pergeseran paradigma
administrasi publik hal ini
menunjukkan $\quad$ bahwa
penyelenggaraan pemerintahan
belum mampu menjalankan
paradigma new public service
atau governance. Governance
menempatkan masyarakat
sebagai kesatuan untuk
memecahkan masalah,
memenuhi $\quad$ kebutuhan
masyarakat, dan terlibat aktif
dalam kegiatan sosial, politik
dan ekonomi (Oborne dan
Geabler, 1992; dalam Rohman,
2012). Titik masuk atau
masalah ini tidak dicari atau
diidentifikasi oleh masyarakat
seperti yang disampaikan
Malena et al (2004), namun
muncul sebagai sebuah masalah
yang dialami masyarakat
sehingga memunculkan
akuntabilitas sosial.

2. Mengelola Informasi dan Menyampaikan Pada Ranah Publik

Masalah yang telah
dikenali harus didukung
dengan adanya informasi yang
jelas, baik dari masyarakat
maupun dari pemerintah.


Informasi ini kemudian diolah disampaikan pada pemimpin dan publik atau masyarakat luas agar diketahui oleh seluruh masyarakat. Kategori dalam elemen ini yaitu:

a. Insidental

b. Manajemen keluhan

c. Penyerahan stempel

Beberapa kategori
tersebut mengerucut pada
kategori inti: kemampuan
masyarakat dalam mengolah
informasi dan menyampaikan
pada pemimpin. Berbeda dengan pandangan Malena et al (2004) dan UNDP (2013) yang menyatakan bahwa informasi atau temuan harus dibawa pada jaringan media sosial dan politik untuk menciptakan debat publik. Informasi dalam akuntabilitas sosial ini justru muncul dari permasalahan yang dialami bersama dan meresahkan masyarakat. Informasi tersebut kemudian diolah dalam pertemuan (musyawarah) dan hasilnya disampaikan pada pemimpin dengan membawa legitimasi dari masyarakat berupa stempel lembaga.

3. Menyiapkan Masyarakat dan Membangun Dukungan

Elemen ini merupakan upaya untuk menggalang masyarakat dan menggalang dukungan atau koalisi. Akuntabilitas sosial masyarakat terjadi ketika ada keluhan yang disampaikan oleh masyarakat. Untuk itu tidak ada usaha khusus yang dilakukan untuk menyiapkan masyarakat.

Sedangkan untuk upaya membangun dukungan dari luar tidak dilakukan. Penggalangan dukungan ini hanya dilakukan pada masyarakat. Sehingga upaya yang dilakukan dalam menggalang dukungan ini adalah mendapatkan legitimasi masyarakat. Pembahasan ini difokuskan pada aktor masyarakat yang terlibat dalam akuntabilitas, yaitu:

a. Kaum Muda

b. Golongan Tua

c. Tokoh Masyarakat

d. Ketua RT dan atau RW

e. Orang tertentu

Kategori tersebut menunjuk pada kategori inti berupa: adanya sinergisitas dalam masyarakat yang membuat akuntabilitas sosial mendapatkan dukungan masyarakat.

Malena et al (2004) dan UNDP (2013) menyatakan bahwa diperlukan penyiapan masyarakat dan membangun 
dukungan untuk akuntabilitas sosial. Sementara akuntabilitas sosial yang muncul dari masyarakat Kelurahan Kalisoro ini tidak melakukan upaya penyiapan masyarakat maupun membangun dukungan dari pihak lain. Masyarakat memiliki kohesivitas dan kemampuan

mengorganisasikan diri yang cukup tinggi. Hal ini yang memunculkan sinergisitas dalam masyarakat sehingga akuntabilitas sosial mendapatkan dukungan dari aktor masyarakat secara langsung.

4. Interaksi dan negosiasi

Strategi efektif untuk menyampaikan tuntutan publik atau kepentingan ini adalah dengan melakukan interaksi dengan pemerintah. Interaksi ini merupakan bentuk komunikasi yang dilakukan masyarakat dengan pemerintah. Media yang digunakan adalah :
a. Demonstrasi
b. Negosiasi
c. Forum evaluasi
d. Tertulis

Beberapa kategori
tersebut mengerucut pada
kategori inti yaitu: adanya
usaha untuk menyampaikan

tuntutan atau isu publik secara langsung dan mendapatkan respon seperti yang diinginkan masyarakat. Sebagaimana disampaikan Malena et al (2004) dan UNDP (2003), interaksi sangat penting untuk menyampaikan tuntutan publik dan memberikan efek perubahan. Elemen ini juga dilakukan oleh masyarakat dengan beberapa media interaksi. Setiap media interaksi yang digunakan ditujukan untuk mendesakkan tuntutan agar tuntutan tersebut dapat didengar dan direspon secara langsung oleh pembuat kebijakan.

5. Respon Pemerintah dan Mekanisme yang Dibangun

Respon disini menjadi tindakan aktif yang dilakukan pemerintah untuk menangkap tuntutan publik dan melakukan perubahan. Akuntabilitas sosial yang dibangun oleh masyarakat Kelurahan Kalisoro mendapatkan respon oleh pemerintah. Namun, secara umum tidak menciptakan sebuah mekanisme baku dan formal yang disepakati antara masyarakat dengan pemerintah. Untuk itulah pambahasan elemen ini fokus pada respon yang diberikan oleh pemerintah 
atas isu publik atau tuntutan masyarakat, yaitu:
a. Respon positif
b. Respon negative

6. Respon Kebijakan

$$
\text { Kategori tersebut }
$$
mengerucut pada kategori inti yaitu berupa tanggapan yang diberikan oleh pemerintah untuk mengakomodir isu publik atau tuntutan masyarakat dan melakukan perubahan menuju arah yang lebih baik. Sebagaimana disampaikan oleh SAP4 Africa (2013), respon pemerintah ini terjadi dalam akuntabilitas sosial serta menjadi elemen penting yang menjamin bahwa isu publik yang dibawa masyarakat dilaksanakan oleh pemerintah. Namun, respon pemerintah ini tidak memunculkan sebuah mekanisme yang formal dan baku dalam akuntabilitas sosial.

\begin{tabular}{lr}
\multicolumn{1}{c}{ Menurut } & UNDP \\
(2013), bahwa & masyarakat \\
perlu membangun & keterlibatan \\
akuntabilitas & dengan \\
pemerintah & sehingga \\
menciptakan & sebuah \\
mekanisme yang disepakati \\
bersama. Akuntabilitas sosial \\
yang dilakukan $\quad$ oleh \\
masyarakat justru berperan \\
sebagai sebuah media kontrol \\
terhadap kinerja pemerintah.
\end{tabular}

\section{Pemantauan Sosial}

Akuntabilitas sosial masyarakat Kelurahan Kalisoro tidak menciptakan mekanisme formal dan baku, oleh sebab itu bangunan akuntabilitas sosial inipun tidak memunculkan bentuk pemantauan sosial yang baku. Sebagaimana perannya dalam mengontrol kinerja pemerintah, akuntabilitas sosial ini juga berperan sebagai sebuah media pemantauan sosial. Meskipun demikian, hasil dari akuntabilitas sosial yang dilakukan oleh masyarakat secara tidak langsung memberikan dampak pengawasan terhadap pemerintah atau pejabat publik. Untuk itu elemen ini fokus pada pembahasan mengenai hasil yang dicapai dalam akuntabilitas sosial, yaitu:
a. Pergantian Lurah karena desakan masyarakat
b. Pergantian Lurah karena kesediaan untuk mundur
c. Dampak tidak langsung

Beberapa kategori tersebut mengerucut pada satu ketagori inti yaitu: hasil yang dicapai dalam akuntabilitas sosial berperan sebagai media kontrol dalam perbaikan kinerja pemerintah. Seperti yang 
disampaikan UNDP (2013) bahwa pemantauan diperlukan untuk menjamin keberlanjutan aktivitas pemerintah, akuntabilitas sosial yang dilakukan masyarakatpun menghasilkan kontrol kinerja pemerintah meskipun tidak menciptakan media khusus. Aktivitas yang dilakukan dalam akuntabilitas sosial ini sendiri merupakan bentuk kontrol terhadap pemerintah.

\section{Gambar 1. Elemen Akuntabilitas} Sosial Masyarakat Kalisoro

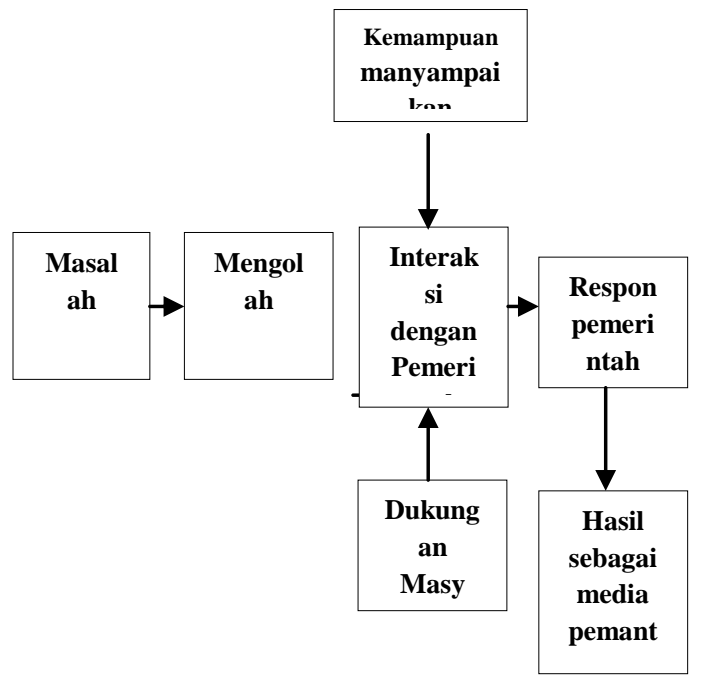

Sedangkan faktor yang berpengaruh dalam akuntabilitas sosial tersebut adalah:
1. Karakter Negara/Pemerintah

Jaminan mengenai keterlibatan warga negara ini sudah ada dalam regulasi di Negara Indonesia. Namun yang menjadi permasalahan adalah bagaimana regulasi tersebut dipatuhi dan dilaksanakan oleh pemerintah atau pejabat publik serta kepahaman masyarakat mengenai regulasi tersebut.

\begin{tabular}{llr}
\multicolumn{2}{c}{ Namun } & beberapa \\
kendala & muncul dalam \\
jaminan & keterlibatan warga \\
negara ini. Kendala ini \\
berasal dari \\
bentuk
\end{tabular}
Kelurahan, yaitu:

a. Regulasi

b. Struktural Hierarkhis

c. Kelembagaan

d. Sumber Daya Manusia

Keterbatasan-

keterbatasan tersebut mempengaruhi keleluasaan dan kemampuan adaptasi lembaga pemerintahan. Sehingga lembaga kelurahan tidak bisa adaptif dalam memenuhi setiap tuntutan masyarakat.

\section{Pembahasan}

selanjutnya memfokuskan pada karakter yang dimiliki oleh pemerintah baik secara kelembagaan maupun 
personal yang menjadi faktor pendorong munculnya akuntabilitas sosial pada masyarakat Kelurahan Kalisoro. Pembahasan ini juga akan memberikan gambaran apakah pemerintah atau pejabat publik berorientasi pada regulasi sudah ada. Kategori yang muncul adalah:

a. Karakter kepemimpinan

b. Politis

c. Sudah pernah menjadi perangkat

Beberapa kategori tersebut mengerucut pada kotegori inti dimana sistem pemerintahan yang sudah mulai terbuka belum disertai dengan kemampuan pemerintah untuk melaksanakan pemerintahan yang humanis (human governance).

\section{Sebagaimana}

disampaikan UNDP (2013), World Bank (2013) dan Malena et al (2004), bahwa karakter negara atau pemerintah ini menjadi jaminan adanya keterlibatan warga negara dalam pemerintah. Pemerintahan Indonesia sebenarnya sudah memiliki regulasi mengenai keterlibatan warga negara, namun implementasinya belum mampu berjalan sebagaimana yang diharapkan. Bentuk negara yang demokratis di Indonesia belum mampu mewujudkan pemerintahan demokratis yang mensyaratkan warga negara atau masyarakat sebagai aktor penting dalam pemerintahan. Belum adanya 'civic minded' penyelenggara negara ini berkaitan dengan variabel keterbatasan bentuk pemerintahan kelurahan yang berupa keterbatasan regulasi, struktural, kelembagaan dan sumber daya manusia.

2. Karakter Warga Negara/ Masyarakat

Faktor ini menekankan kapasitas yang dimiliki atau melekat pada aktor masyarakat sehingga mendorong masyarakat untuk terlibat dan proaktif dalam akuntabilias sosial. Karakter masyarakat yang mampu mendorong tumbuhnya akuntabilitas sosial adalah masyarakat dengan kapasitas politik untuk membuat aksi kolektif (UNDP, 2013), memiliki kemampuan berbicara atas nama konstituen, kemampuan manajerial, advokasi, interaksi dan 
negosiasi dengan pemerintah, membangun jaringan, membangun informasi, kepemimpinan, independensi (Ackerman, 2004 dan Worl Bank, 2006). Beberapa karakteristik masyarakat tersebut antara lain:
a. Nilai masyarakat desa
b. Kemampuan mengorganisasikan diri
c. Independensi masyarakat

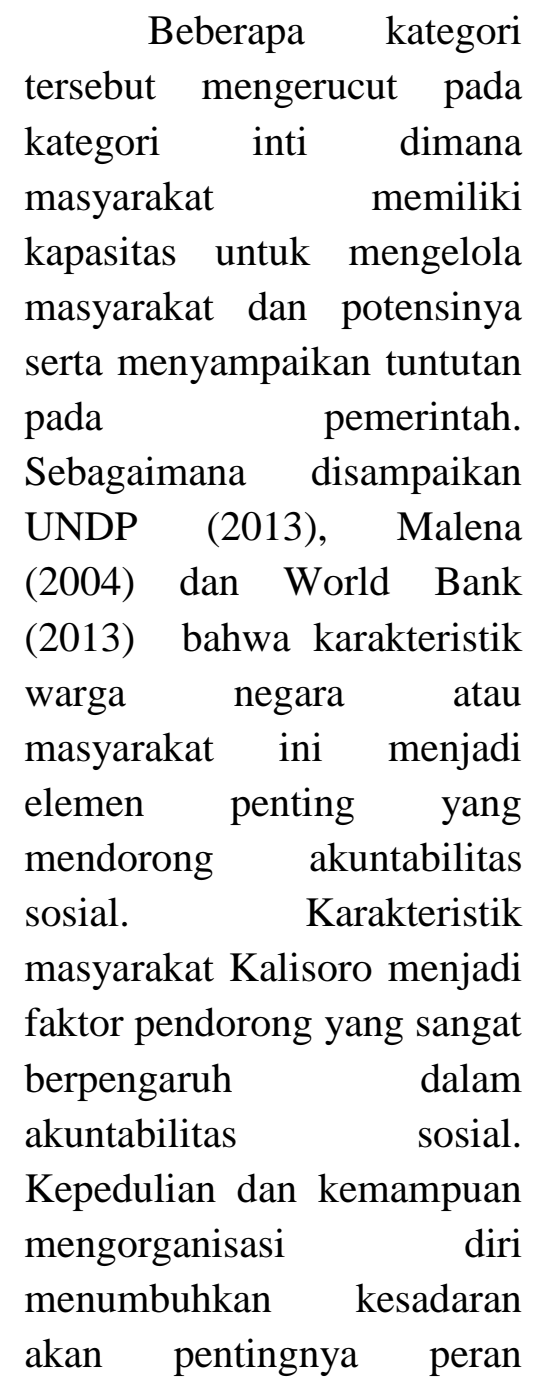

masyarakat dalam penyelenggaraan pemerintah dan pembangunan masyarakat. Kapasitas ini membuat masyarakat mampu terlibat aktif untuk perbaikan kinerja pemerintah maupun membuat pemerintah lebih akuntabel. Seperti disampaikan Ackerman (2004) bahwa masyarakat merupakan kekuatan potensial untuk mempertajam akuntabilitas pemerintah. 


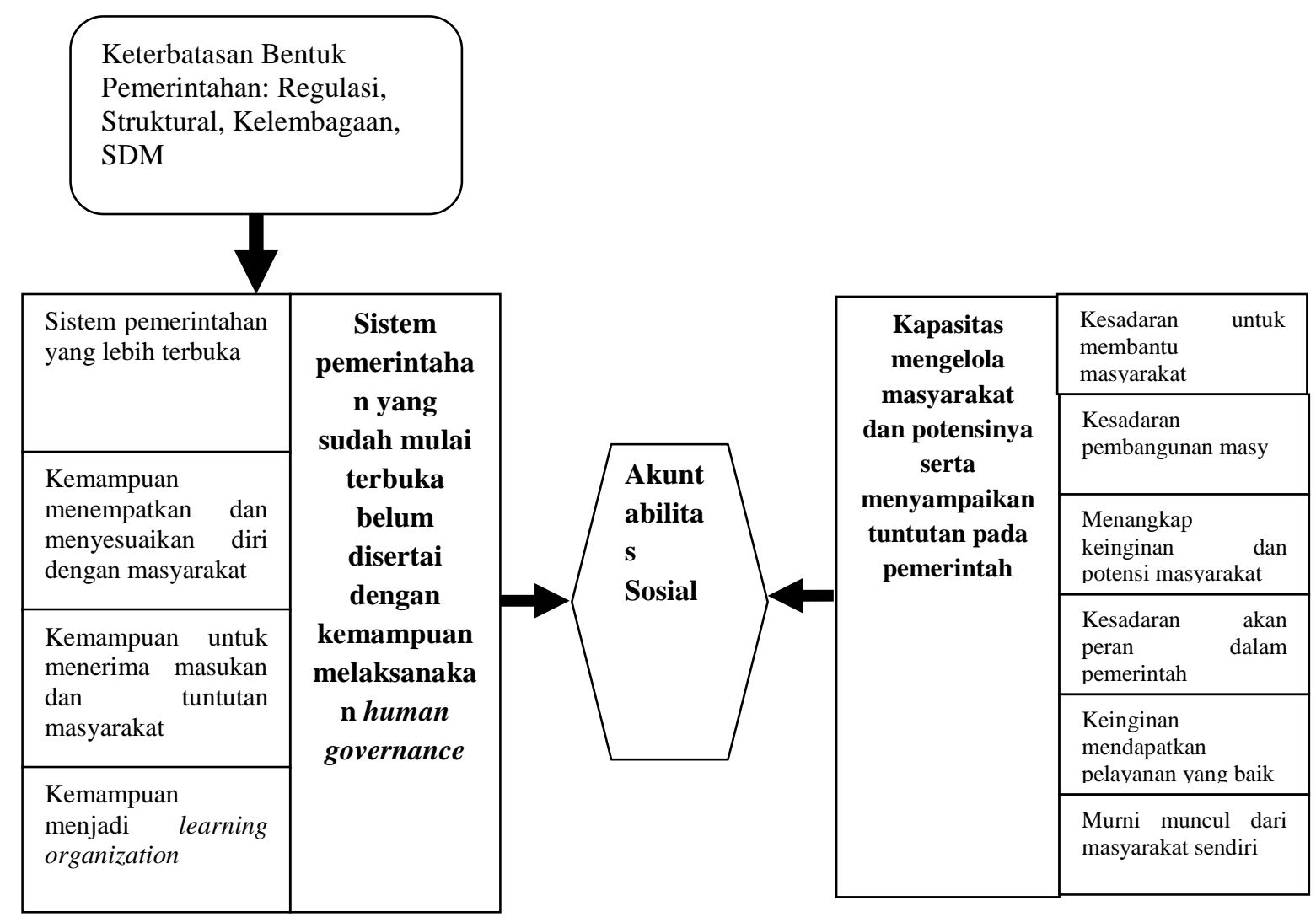

\section{Gambar 2. Faktor yang mempengaruhi Akuntabilitas Sosial pada Masyarakat Kalisoro}

\section{KESIMPULAN}

Kesimpuan dari penelitian yang dilakukan adalah sebagai berikut:

1. Akuntabilitas Sosial masyarakat Kelurahan Kalisoro terbentuk karena adanya titik masuk berupa kurangnya kemampuan pemimpin, masalah yang muncul tersebut diolah dan disampaikan pada pemimpin dengan dukungan dari masyarakat melalui media demonstrasi, negosiasi, dan forum evaluasi kinerja dimana akuntabilitas sosial tersebut tidak membangun mekanisme dan pemantauan sosial tertentu.

2. Faktor yang mempengaruhi terbentuknya akuntabilitas sosial yaitu: Pertama, Karakter negara atau pemerintah, yaitu kemampuan untuk melaksanakan pemerintahan yang humanis (human governance). Kedua, karakter warga negara atau masyarakat, yaitu kemampuan untuk mengelola potensi masyarakat dan berhubungan dengan pemerintah.

\section{SARAN}

Saran yang diberikan berkenaan dengan penelitian yang dilakukan adalah:

1. Pembuatan regulasi yang menguatkan responsivitas dan pelayanan sosial (standar kemampuan sosial) lembaga Kelurahan.

2. Memperbaiki dan mengoptimalkan lembaga kemasyarakatan yang memiliki peran sebagai kontrol kinerja Pemerintah Kelurahan.

3. Pemerintahan Kelurahan perlu melakukan perubahan pola 
pelayanan publik yang lebih humanis.

4. Membuat forum pertemuan rutin dengan masyarakat setiap bulan. Forum ini dimanfaatkan sebagai media komunikasi yang efektif antara pemerintah dengan masyarakat dalam membangun mekanisme penyampaian masukan atau tuntutan ataupun penyampaian kebijakan.

\section{DAFTAR PUSTAKA}

Ackerman, John M. 2005. Social Accountability in the Public Sector: A Conceptual Discussion. Social Development Paper: Participation and Civic Engagement, Paper No.82/March 2005. Diakses dari: http://documents.worldbank.org/cu rated/en/2005/03/6705775/socialaccountability-public-sectorconceptual-discussion. 23 Januari 2015

Bovens, Mark. 2006. Analysing and Assesing Public Accountability: A Conceptual Framework. European Governance Paper, No C-06-01. Diakses dari: http//www.connexnetwork.org/eurogov/pdf/egpconnex-C-06-01.pdf. 23 Januari 2015

Chiovitti Rosalina F dan Niva Piran. 2003. Rigour and Grounded Theory Research. Metodological Issue in Nursing Research. Journal of advanced Nursing.

Farazmand, Ali. 2002. Administration Reform In Developing Nations. London: Preager
King, Rudith et al. 2013. Social Accountability For Local Government in Ghana. Commonwealth Journal of Local Governance Issue 13/14: November 2013. Diakses dari: http://lib.uts.edu.au/ojs/index.php/c jlg. 31 Januari 2015

Kumorotomo, Wahyudi. 2005. Akuntabilitas Birokrasi Publik: Sketsa Pada Masa Transisi. Yogyakarta: Pustaka Pelajar.

Malena, Carmen, et al. 2004. Social Accountability: An Introduction to the Concept and Emerging Practice. Social Development Papers: Participation and Civil Engagement Paper No.76 December 2004. Diakses dari: http://siteresources.worldbank.org/ INTPCENG/214578$\underline{1116499844371 / 20524122 / 310420}$ PAPER0Solity0SDP0Civic0no107 6.pdf. 23 Januari 2015

Pattiro, 2014. Akuntabilitas Sosial dan Open Govenrment, 5 Februari 2014. Diakses dari: http://pattiro.org/?p=3257\# ftn12. Pada 31 Januari 2015

Punch, Keith F.1999. Introduction to Social Research: Quantitative and Qualotative Approach. London, Thousand Oaks, New Delhi: SAGE Publications.

Rohman, Ahmad Ainur, 2012. Posisi Civil Society dalam Good Governance. Rohman dkk; Partisipasi Warga dalam Pembangunan dan Demokrasi, Malang: Averroes Press

SAP4Africa. 2013. Building of social accountability.Diakses dari: 
http://www.sap4africa.net/building

-blocks-social-accountabilityl. 23

Januari 2015

Saptawan, Andriyan. 2010. Perkembangan

Praktik Ilmu Adminitrasi Negara.

Falih Suhaedi dan Bintoro

Wardiyanto. Revitalisasi

Administrasi Negara: Reformasi

Birokrasi dan E-

Governance.Yogyakarta: Graha Ilmu

Setyawan, Donny. 2014. Akuntabilitas Sosial sebagai Instrument Penilaian Birokrasi Pelayanan

Publik. Disampaikan pada Pertemuan Puncak Reformasi Birokrasi Nasional (RB Summit), 9-10 September 2014, Jotel JS Luwansa, Jakarta

Thoha, Miftah. 2011. Ilmu Administrasi Publik Kontemporer. Jakarta: Kencana Prenada Media Grup

UNDP. 2013. Catalyzing Democratic

Governance to Accelarate Progress Towards the Millenium Development Goals. Reflection on Social Accountability. New York.

Diakses dari:

http://www.undp.org/content/dam/ undp/documents/partners/civil_soc
iety/2013_UNDP_Reflections-onSocial-Accountability EN.pdf. 23 Januari 2015

Utomo, Warsito. 2006. Administrasi Publik Indonesia Di Era Demokrasi Lokal: Bagaimana Semangat Kompabilitas Menjiwai Budaya Birokrasi. Fakultas Ilmu Sosial dan Ilmu Politik. Pidato Pengukuhan Guru Besar Universitas Gajah Mada. Yogyakarta: Gadjah Mada University Press

World, Bank. 2006. Social Accountability: What Does It Mean for the World Bank?. Social Accountability Sourcebook Chapter 2. Diakses dari:

http://www.worldbank.org/socialac countability_sourcebook/PrintVers ions/Conceptual\%2006.22.07.pdf 23 Januari 2015 http://jogja.solopos.com/baca/2014 /01/18/warga-kalisoro-tuntut-lurahmundur-482918

PP No. 73 Tahun 2005 Tentang Kelurahan

Keputusan Menteri Pendayagunaan Aparatur 63 / KEP / M.PAN / 7/2003 tentang Pedoman Umum Pelaksanaan Pelayanan Publik 